\title{
Poliitiline anekdoot. II
}

$\underline{\text { Kadi Sarv }}$

\section{Poliitiline anekdoot sõja- ja saksa okupatsiooni aastatel (1939-1945)}

II maailmasõda algas 1939. aastal sakslaste ja venelaste sissetungiga Poolasse. Tõhusat abi ei olnud Poolal kusagilt loota. Lääne-Euroopa riikide "sõjategevus" piirdus peamiselt propaganda ja majandusliku survega.

Poola küsind Lätilt abi, saatke tanke. Ulmanis küsind vastu - kas saadan ühe või mõlemad kaks.

Mitu surnut on seni läänerindel? - Kaks. Üks suri igavusest ja teine sai lendlehtede pakiga pähe.

Inglise lahingulaev sõidab Põhjamerel. Järsku tehakse kuuldeaparaadiga kindlaks, et läheduses viibib saksa allveelaev. Kapten käsutab: "Tuuker klaariks! Lendlehtedega alla!"

1939. aastal sõlmitud baaside lepingu järel Eestisse sisenenud Vene väed, kellele ilma ühegi püssipauguta loovutati Eesti vabadus, jätsid eestlastele sügava mulje.

Mõista, mõista, mis see on? Viiekümne peaga, kõht vastu selga ja selg vastu kõhtu, kui seisab, siis haiseb, kui liigub, siis karjub? - Näljased vene sõdurid.

Kas armastusjumal Amor oli kreeklane või itaallane? - Venelane, sest tal on paljad kannikad ja relv peos.

Okupeeritud Eesti rahva põhiline mure järgnevate sõja-aastate jooksul oli kõrvalehoidmine küüditamistest ja erinevatest mobilisatsioonidest:

Milline riik on maailma suurim riik? - Eesti. - Tema piir on Läänemerel, pealinn on Moskvas ja parimad pojad Siberis.

1941. aastal, kui küüditamine olnud, saadetud taevast ingel alla, vist olukorda kontrollima. Ingel pole tagasi tulnud. Saadetud teine, kolmas jne. Lõpuks läinud Peetrus ise asja järele uurima, temagi pole tagasi tulnud, kuid tüki aja pärast saatnud telegrammi: "Zhiv i zdorov. Komissar Petrov." 
A vat saksa aegas oli üks anekdoot. Siis /.../ hakkasid eestlasi mobiliseerima. Taheti sõjaväest ära hoida ja üks tee oli niisugune, et sind vangi pannakse. Mees läks komandatuuri ja ütles, et: "Ma mü̈̈sin mune!" Komandant ütend: "Kas veel on? Ma tahan ka!" Siis rääkind ühe anekdoodi Hitlerist, hullu. Komandant ütlend: "Ma tean veel hullemad!" ja rääkind omakorda. Siis tõusnud mees püsti ja pand sel komandandil vasta vahtimist. Komandant karand hirmuga püsti, et: "Kas venelased on juba niikaugel."

Anekdootides kirjeldatakse ja antakse hinnang Saksamaa ja Hitleri maailmavallutajalikele ambitsioonidele:

Kunagi oli Saksamaal kuningas, kes silitas oma habet ja ütles rahulolles: "Saksamaa on suur, Saksamaa on suur!" Kunagi hiljem oli Saksamaal üks keiser, kes keerutas oma suuri vurre ja muheles: "Meil on maad, meil on maad." Nüüd on Saksamaal Hitler, kes kratsib nimetissõrmega mokahabet ja ütleb: "Kust saaks juurde, kust saaks juurde!"

Kui sõda algas, vaatles kord Hitler kabinetis oma pilti ja küsis pildilt: "Mis siis on, kui ma sõja võidan?" Pilt vastas: "Siis on Sul suur au!" "Aga mis siis, kui ma sõja kaotan?" "Siis ripud sina minu asemel."

Hitleril õnnestub isegi kahtlevat Jumalat üle trumbata ja tõestada, et saksa rahvas toetab teda kõigis tema ettevõtmistes. Tänaste kooliõpilaste naljarepertuaaris esineb sama süzhee kolme rahva anekdoodina, kus kõige nupukamaks osutub hoopis venelane, kes sabaalust lakkuva ja näuguva kassi tegevust kommenteerib: "Sööb vabatahtlikult ja lauluga!"

Jumal kutsus sõdijate riikide valitsejad kokku, kõik ütlesid: "Rahvas tahab ise sõdida." Jumal ütles: "Andke kassile sinepit, kas ta tahab seda süüa, siis ma usun, et rahvas tahab sõdida." Kõik Jaapan, Ameerika, Vene, Inglise, Itaalia - panid kassile sinepit nina alla, aga kass ei katsunudki kõigist nende meelitamisest hoolimata. Hitler võttis sinepit, pani kassile saba alla, kohe kass kükitas maha ja lakkus sabaaluse puhtaks. Hitler ütles: "Mina panen oma rahva kõik tegema, mis ma tahan."

Hoolimata Hitleri fanaatilisest usust ja võidutahtest toimub sõja käigus murrang. Üha rohkem leidub kahtlejaid sõja mõttekuses ja võidu võimalikkuses.

1941. a. peab Hitler paraadil kõne. Sõdurid karjuvad: "Füürer, me järgneme sulle!" 1943. aastal peab Hitler Idarindel sõduritele kõne, mille lõpul teatas, et naaseb koju. Sõdurid röögatavad: "Fü̈rer, me järgneme sulle!"

Hitler läheb Napoleoni haua juurde, hü̈̈ab: "Kiiev ja Harkov on võetud." Napoleon hauast: "Hea küll." Hitler ütleb: "Hakkan Stalingraati võtma." Hauast vastatakse: "Hea küll." Viimaks Hitler hü̈ab: "Siis lähen Bakuu peale." Hauas jääb kõik vaikseks. Hitler küsima: "Kuule, miks Sa ei 
vasta?" Vastuseks kostub kolin ja siis ka Napoleoni sõnad, et ta valmistavat Hitlerile kohta enda kõrvale.

Eestlaste vastumeelsusest Hitleri ja saksa sõjaväe suhtes annab pildi ühe saksa sõjaväes viibinud eestlase meenutus, et kui rivistusel ülem neid tervitas: "Heil Hitler!", siis eesti poisid vastanud üksmeelselt: "Ei ütle!"

Hitler ütleb oma arstile: "Kui ma noor olin, siis olin ma psühhopaat." Arst: "Aga te ei ole ju sugugi vana, mu füürer!"

Göring ja Hitler sõidavad külavahel ühe sea surnuks. Hitler ütleb: "Mine sinna majja ja paku sea eest raha." Veidi hiljem tuleb Göring tagasi, käed pakikesi täis. Ise seletab: "Ma ei tea, miks nad nii õnnelikud olid! Mina ütlesin: "Heil Hitler, siga on surnud!", ja näed, mis nad mulle andsid."

Hitlerist rääkides ei saada mööda tema juutide vihkamisest.

Kui Hitler taevasse jõudis hakkas ta järsku märatsema: "Siin on üks juut, ajage ta välja! Muidu ma lähen minema!" Peetrus ütles: "Pst, olge tasa! See on peremehe poeg."

Kui varasemates naljalugudes esinevad ühesuguses omavolilise võimuhaaraja rollis Hitler ja K. Päts (Jumal ei julge nende läheduses toolilt tõusta, sest nad võivat tema koha hõivata), siis tänapäeva koolilaste anekdootides tegutseb Hitler enamasti koos Staliniga. Ka asendavad nad samas naljanditüübis üksteist - rahvasuu on nad ühe ajastu despootidena peaaegu samastanud.

XXI sajandi entsüklopeediast: "Hitler: stalinistliku epohhi väike türann."

Okupatsiooni-aegsetest omavalitsustegelastest on anekdootides naerualuseks kõige enam Hjalmar Mäe:

Kaks eesti naist vestlevad omavahel uudistest. Üks küsib teiselt: "Kas teate, miks raadio ei anna enam soovikontserte? ... Rahvas soovib, et Litzmann ja Mäe laulaksid duetti "Hakkame mehed minema, kodu poole kõndima".

Üks mees läinud okupatsiooni-ajal maanteel. Tee ääres oli söönud väike niidetud lammas. Mees oli küsinud, et kuule talleke, kes sind nii paljaks püganud on. Tall oli aga õige ruttu vastanud: "Mäemäe-mäe!"

Raskest majanduslikust olukorrast sõja ajal räägivad naljalood, kus enesetappu sooritavale SS-lasest ohvitserile soovitatakse elatada end eestlaste toidukaardiga - kahe nädalaga olevat surm kindel, või kus sõnnikut osta tahtev talumees peab tõdema, et saksa raha eest ei saa sitta ka osta. 
Keegi mees läinud vallamajja lehma ostuks luba saama. Küsib: "Kas saate mulle müüa säärast lehma, kes on nii kirju kui Hitleri elulugu, nii paks kui dr. Mäe ja nii hästi lüpsab kui Eesti riik?"

II maailmasõja teemaga haakuvad praeguste laste repertuaaris olevad anekdoodid Müllerist ja Stirlitzist. Need omapärased paroodiad on inspireeritud populaarsest filmist "Seitseteist kevadist hetke", kus vapper nõukogude luuraja (Stirlitz) veab ninapidi Saksa armee ja gestaapo kõrgemat juhtkonda ning väljub intriigidest alati võitjana. Sisult kuuluvad need jutud küll pigem absurdihuumori valdkonda, kuid ka poliitiline taust on neil olemas.

Müller ja Bormann istuvad kohvikus. Müller rõõmustab: "Nüüd tuleb Stirlitz ning tellib ühe õlle ja 2 viinerit. See on parool. Ja siis võtame ta kinni." Tuleb Stirlitz, tellib ühe ôlle ja ütleb: "Viinerit pole vaja," - ning näitab Müllerile keelt.

Müller leiab Stirlitzi oma kabinetist Üeifi eest. Müller: "Mis sa siin teed?" - Stirlitz: "Ootan trammi." Müller lahkub viivuks. Kui ta tagasi tuleb on Stirlitz kadunud. Müller mõtleb: "Ära sõitis vist."

Stirlitz kõnnib metsas. Keegi koputab vastu puud. "Rähn," mõtleb Stirlitz. "Ise oled rähn," mõtleb Müller.

Müller sõidab autoga $70 \mathrm{~km} / \mathrm{h}$. Heidab pilgu peeglisse ning näeb: tema kannul jookseb Stirlitz ja teeb näo nagu jalutaks.

Suhtumist võidukasse Punaarmeesse ja tema võidu põhjustesse väljendavad eriti ilmekalt just keerdküsimused.

Taevas on kolm saksa lennukit ja üks vene lennuk, kes võidab? - Võidab venelane, sest ta on kommunist.

Käib äge lahing. Äkki kuulipilduja vaikib. Kuulipildur: "Komandör, padrunid said otsa!" - "Oled sa kommunist või mitte!" - Ja kuulipilduja hakkab veel ägedamalt tärisema.

Mitu võitu oli venelastel Suure Isamaasõja ajal? - Kolm: põhjas külmavõitu, lõunas soojavõitu , muidu üldse sitavõitu.

Stalin tegi II maailmasõjas 2 viga: I näitas vene Ivanile Euroopat, II näitas vene Ivani Euroopale. 
Kust tshehhid teavad, et Maa on ümmargune? - 1945. aasta sügisel ajasid nad okupandid läände, 1968. aastal tulid nood idast tagasi.

II maailmasõja lõpus Jaapanile heidetud aatompommid viivad inimesed järgmise sõja hukatuslike tagajärgede mõistmiseni.

Milline tuleb III Maailmasõda? - Ei tea, aga neljas tuleb kaigastega.

Levib sõjavastane hoiak, kuid ka rahuvõitlusse suhtutakse skeptiliselt.

Kas tuleb sõda? - Ei, aga tuleb niisugune võitlus rahu eest, et kivi kivi peale ei jää.

Rahvad nõuavad rahu ja nad peavad seda saama, mingu see meile või miljoneid inimelusid maksma.

Sõja lõpus eestlaste seas levinud optimistlik hoiak vene võimu ajutisusest Eestimaal annab peagi maad lootusetusele.

Mis vahe on ameeriklasel ja venelasel? - Ameeriklane läks Kuule ja tuli tagasi. Venelane läks üle Peipsi ja ei tulnud tagasi.

Mees on hädas prussakatega. Läheb targa juurde nõu küsima. Tark annab mehele üleskeeratava prussaka. Et keeraku see üles ja lasku oma korterist välja minna. Siis teised prussakad lähevad talle järele. Varsti läheb mees targa juurde üleskeeratavat venelast küsima.

Protest nõukogude võimu vastu väljendub muuhulgas kogu vene rahvuse halvustamises.

Mis on eestlase ja venelase vahe? - Eestlane räägib suuga ja töötab kätega, venelane räägib kätega ja töötab suuga.

Mis vahe on noa andmises eestlasele ja venelasele? - Eestlasele annad noa pideme poolega, venelasele annad nuga tera poolega.

Ka kolme rahva lugudes, kus eesti anekdoodirepertuaaris tegutsevad enamasti eestlane, sakslane ja venelane (seesugusel rahvaste valikul on ajaloolis-poliitilised tagamaad), omab viimane kõige madalamat staatust. 
Eestlane, venelane ja sakslane sõidavad lennukis. Jõuavad Saksamaa kohale. Sakslane viskab "Marlboro" paki alla, ütleb: "Seda kraami on meil kõige rohkem." Jõuavad Venemaa kohale. Venelane viskab viinapudeli alla, ütleb: "Seda on meil kõige rohkem." Jõuavad Eestimaa kohale. Eestlane viskab venelase alla, ütleb: "Neid on meil kõige rohkem."

Vene riigitegelaste, kommunistliku ideoloogia ja nõukogude võimu pilamine jõuab haripunkti pikkadel nõukogude okupatsiooni aastatel. 